\title{
A Critique of Njabulo Ndebele's Criticism of Protest Fiction
}

\author{
Dr Theophilus T Mukhuba \\ Senior Lecturer of English at the North-West University \\ Email:11284722@nwu.ac.za
}

\section{Doi:10.5901/mjss.2014.v5n20p2359}

\section{Abstract}

In his critical writings contained in his book, Rediscovery of the Ordinary: Essays on South African Literature and Culture, Njabulo Ndebele propagates the view that black South African writers during the struggle years persistently wrote about the political environment and the conditions in which they found themselves, and are therefore guilty of simply making political statements rather than advancing an artistic perspective in their writing. He contends that in the process of doing so, they have disregarded the artistic value of literature in its more encompassing form. In March 1984, the magazine Staffrider, a South African literacy magazine, published an article entitled 'Turkish Tales and Some Thoughts on South African Fiction' in which Ndeblele singles out witers like Mothobi Mutloatse, Sipho Sepamla and Miriam Tlali as examples of writers who cause a certain degeneration in literacy art. This accusation, as this article will attempt to show, is largely unfair in view of the fact that his own fictional works cannot really be differentiated form those which he criticizes for their overtly political content. In fact, it appears that Ndebele strives to draw a distinction between him and these writers on theoretical grounds alone. He does this by offering alternative forms of literary expression which are not necessarily acceptable to all literacy artists, as literary composition does not necessarily have to subscribe to a particular school of literary art. In practical terms, as we shall see, there is often very little to choose between his fiction, which he produced during the Apartheid era, and the fiction of those he criticizes.

\section{Introduction}

In advocating a particular form of literature, Ndebele overlooks the fact that a writer does not write in a vacuum. The writer cannot divorce himself from his environmental influences, and these influences more often than not manifest themselves in his work.

Perhaps the question that needs to be asked is: "What is literary art and what form should it take?" The answer to the question would surely vary from critic to critic, but it must be pointed out that those who aspire to answer the question should guard against being too prescriptive.

It should be pointed out that the term 'literature' has been defined relatively and broadly throughout the ages. Broadly, the view was that 'literature' was anything in print. Rene Wellek (1990) in a chapter called "What is Literature?" traces the various different definitions relative to certain periods and concludes by observing that:

In all of these cases literature is used very inclusively. It refers to all kinds of writing, including those of erudite nature, history, theology, philosophy, and even natural science. Only very slowly was the term narrowed down to what we today call 'imaginative literature': the poem, the tale, the play in particular. This is a process intimately connected with the rise of aesthetics (1978:19).

Hernadi (1978) states that the question 'what is literature?' is a basic yet troublesome question and that it cannot be answered to anyone's complete satisfaction. The history of literature studies bears the hallmarks of numerous critical attempts to define literature. It therefore suffices to acknowledge that, in view of the divergent views expressed on the nature of literature, the commonality in opposition is that literature is a relative form of expression. A surface position on what literature is is that it is largely shaped by the conditions within which it is produced. An example of the relativity of the term literature can best be noticed in African literature.

Shave (1989) argues that in African literature there is considerable comment on the issue of commitment. He ascribes this to Africa's colonial experience and the fact that political commitment has tended to be more pragmatic than theoretical. Fanon (1968) points out that those twentieth-century writers espouse commitment in different ways. He argues that colonialism created cultural disorientation, alienation and economic domination for Africans.

Taking his cue from Fanon, Chinua Achebe maintains that it is the task of the African writer to help his society regain its lost dignity, identify, values and customs:

What we need to do is to look back and try and find out where we went wrong, where the rain began to beat us. 
The writer cannot expect to be excused from the task of re-education and regeneration that must be done. In fact he should march right in front. For he is after all ...the sensitive point of his community (1975:44-45).

Ngugi wa Thiong'o argues for a more involved form of political involvement. He expresses a belief that:

...literature cannot escape from the class power structures that shape our everyday life. Hence a writer has no choice. Whether or not he is aware of it, his works reflect one or more aspects of the intense economic, political, cultural and ideological struggles in a society. What he can choose is one is one or the other side in the battlefield: the side of the people, or the side of those social forces and classes that try to keep people down. What he or she cannot do is to remain neutral. Every writer is a writer in politics. The only question is what and whose politics? (1981:58)

The assertion highlights the view that literature is always produced to propagate a particular social and/or political agenda. Because the political situation in South Africa dominates all aspects of life in the country, commitment among black writers has been seen as a necessity. As Nazareth (1972:22) points out:

\begin{abstract}
Apartheid affects every aspect to a person's life like a virulent form of cancer. Hence many South African writers \{and, I would say, nearly all black and 'coloured' South African writers\} are concerned with fighting Apartheid, with demonstrating how monstrous Apartheid is, with showing how it dehumanizes everybody.
\end{abstract}

It cannot be denied that the form of literary expression advocated and practiced by most Black South Africans and as preached by the likes of Ngugi has it detractors. Ndebele and Nkosi are at the forefront of the onslaught on protest literature. Nkosi complained about the general method of black fiction writer thus:

What we do get from South Africa and what we get most frequently is the journalistic fact parading outrageously as imaginative literature. We find here a type of fiction which exploits the ready-made plots of racial violence, social apartheid, interracial love affairs which are doomed from the beginning, without any attempt to transcend or transmute their given social facts into artistically persuasive works of fiction (Nkosi: 1965,126).

In Rediscovery of the Ordinary: Essays on South African Literature and Culture, Ndebele echoes this sentiment. It should perhaps be pointed out that the argument against Ndebele's criticism of what has come to be regarded as protest South African literature has nothing to do with the validity of his argument. On the contrary, I think, to some degree and a different scenario to Apartheid permitting, much sense could be derived from his opinions on how literary art should be expressed. What one may object to are the unwarranted attacks on black South African writers such as Miriam Tlali, Sepamla and Mutloatse. So although one may agree with some of the points he makes, one might feel strongly that some of the claims he makes with regard to literature in general and the particular writers mentioned above, are quite inappropriate. It is on this question of 'inappropriateness' that this article bases its argument.

Furthermore, I intend to make an examination of Ndebele's collection of short stories entitled Fools and Other Stories and a short story called "Death of a son' with a view to making a comparison between these works and the 'protest' fiction of the writer-critics he attacks for 'making cases' in literature when they should, according to him, be engaged in 'storytelling'.

It is also hoped that it will be shown that Ndebele's contention that 'the moralistic ideology of liberalism has forced our literature into a tradition of almost mechanistic surface representation' (1984:46), is a crude judgment on those he regards by implication to be hapless victims of this 'tradition'. This is to deny them any sense of creative intervention. While I agree with the assertion that 'the moralistic ideology of liberalism' has had a tremendous influence on protest fiction, I strongly object to the notion implied in the statement that protest fiction is simply a hand-maiden to this 'moralistic ideology of liberalism'.

It is important to note that Ndebele is not alone in his perspective on black South African protest fiction. In his nearveneration of Ndebele as both critic and writer, Michael Vaugham reinforces Ndebele's criticism in this regard as 'a striking innovative enterprise' (1982:24). He also adds to this praise the words: 'I feel he has changed the orientation of my own thinking about literature considerably' (1988:24).

It is interesting in this regard to observe that Ben Okri, winner of the 1992 prestigious Booker Prize for his novel The Famished Road, states his views on African protest literature with this assertion:

I don't think writers should hammer their own personal political viewpoints in their novels; that is bad manners and just plain boring. You can generally detect the sympathies of a writer through the reflecting mirrors in their works. (Exact Source unknown) 
Okri, like Ndebele, obviously holds the view that too much political content in literature debases it in terms of artistic value. In asserting his point, Okri argues that "one of the most awkward things about African literature has been the preponderance of politics" (ibid). But Okri shows an insight different from that of Ndebele when he adds that this development is not surprising because the African writer's condition on the continent is very different and difficult, full of pain and suffering. He understands that writers want, more than anything else, to change things. Ndebele conveniently allows this reality to escape him. After all, an acceptance of Okri's perception would nullify his opinion about literature.

\section{Ndebele's Literary Position - The City and Politics}

Ndebele claims to have come to his realization about the over-politicized nature of contemporary black South African fiction after he had read the Turkish writer, Yasher Kemal's stories. In the article "Turkish Tales..." he points out how he was jolted into a new awareness of literature and particularly the way South African literary works seem to project a city perspective. 'The city' he points out, appears to have held a tyrannical hold on the imagination of the average African worker' (Cromwell, 1992:16). This assertion is prompted by his belief that protest fiction is about the writer's fascination with his immediate political situation - which is a bad situation in most cases - and it also seems to involve an inability to change such circumstances.

One must note that Ndebele does not fully and comprehensively take a historical perspective on the situation in South Africa. With the advent of industrialization in South Africa, particularly after the First World War, black people migrated to the cities. It is in these cities that they became direct victims of oppression.

The contact between the black man and the white man resulted in the white man establishing his superiority through the use of arms over the black man and this obviously led to the domination of the black man by the white man. The white man built cities after the discovery of rich minerals and it was the wealth that the city symbolized that lured the black man to these cities. To ensure his survival particularly in the city, that black man had to conform to the white man's ways and this made him vulnerable to direct exploitation and oppression. Consequently, the black man's bitterest experiences and exploitation and oppression have always largely been in the city. Although the black person is subjected to quite similar circumstances of exploitation and oppression, regardless of where he lives in South Africa, it is still the city dweller that is closer to the unfortunate reality of exploitation and oppression, and usually he can therefore express the bitterness, frustration, fear and hope of the black people. When he projects his experiences and observations in his writings from a city perspective, the black writer is normally using the city only as a microcosm of the whole country.

Ndebele argues that because protest fiction is on the whole a portrayal of bitterness in an urban setting it therefore tends to propagate strong political statements or simply invokes pity form the white liberal by drawing his attention to the plight of the black man in urban South Africa. But what Ndebele conveniently fails to point out is that such literary projections are not necessarily a reflection of the writer's ignorance about other aspects of life in South Africa as a whole. It is just that the black writer who writes in the English language is almost invariably located in the city and his public is usually also found there. In response to Ndebele's criticism, Sipho Sepamla made some interesting observations when I interviewed him on the $6^{\text {th }}$ May 1992. He stated:

Writing is a spontaneous exercise, and because of this, the writer is almost overwhelmed by the environment within which he writes.

He added that he understood Ndebele's criticism since it reflects this fact. He also pointed out that it is all very well for Ndebele to advance his type of literacy perspective as he spent most of his formative years in Lesotho, as Lesotho is a rural and urban environment in one. Ndebele thus straddles two worlds. While he is South African by birth he spent his childhood in Lesotho, he has lived for much of his adult life in a different setting than the black writer who, like Sepamla, has borne the brunt of oppression directly. Most of his literature is about expressing immediate feelings and experiences, directly and/or indirectly, feelings and experiences not based on foreign influences.

In an article entitled 'Evaluating Protest Fiction', Gareth Cromwell defends the artistic integrity of the writers Ndebele criticizes. He explains that literature is diverse and that every literary concept has a "degree of specifically literary sophistication". He also shows an understanding of why black protest friction is almost inevitably projected from a city perspective. Having explained why this is so, he concludes by observing that:

It is not all surprising that social experiences in most 'protest literature' recur and are projected from a city perspective. Cities have always been vehicles and the centre-stage of (social) change in general (1992:12)

Cromwell obviously implies here that it is legitimate for literature to be projected from a city perspective if the 
situation warrants it. In a society like the former South Africa, black people have had their social existence distorted or suppressed by a system perpetuated in the name of western civilization which has the city as its most prominent centre and force for change. It is quite understandable, therefore, that urban black writers would try to address their reading public and their own situations through a city setting. These writings were certainly a sharing with their reading public a common realistic experience.

Clearly one is not suggesting here that their reading public consisted of black people only. Of course their works were also read by a small portion of the white community: the so called 'white liberals'. But one must note that black writers like Sepamla vehemently stress that their intended public was the black reader.

What one finds rather disturbing is Ndebele's claim in 'Turkish Tales...' that he became aware after reading the Turkish writer Yasher Kemal's stories, that he 'did not remember ever coming across as compelling an imaginative recreation of rural like in a body of literature in South Africa'. If one wants to do justice to Ndebele and his criticism, this statement can only be ascribed to his desire to transform the scope of literature in South Africa.

However, such an assessment can also be construed as a gross oversight on the part of Ndebele. This is not to take anything away from Kemal and his efforts. On the contrary, his stories can no doubt be regarded as great literary art. But to use Kemal's stories as a departure point for an analysis of black South African literature is to display lack of understanding of 'protest literature' and its origins and influences. It is also an oversimplification of perspective. Kemal writes about peasant life in Turkey as a matter of choice. Of course he does speak for the suppressed rural peasantry in Turkey. But he is also acknowledged to be a Turk by every description. The black South African writer, on the other hand, was denied his identity and the full expression of that identity. Unlike Kemal, the black writer is part of the experiences he portrays and not just a sympathetic observer who only gets involved through his writings.

Kemal can certainly embark on literary explorations in his native land but the black writer does not perhaps have this degree of choice. This does not in any way imply that the black writer was artistically stereotyped because he kept harping on one topic by allowing the preponderance of politics in his writings. The black writer's feelings on this can best be expressed by the answer given by Mbongeni Ngema in an interview on television about the state of drama in South Africa. He said: "As an artist I will write about change when I see change".

As noted previously, Ndebele is not alone in his insistence that fiction writers should tell stories rather than simply document their observations. Writers such as Lewis Nkosi and Michael Vaughan share the same literary perspectives. My disagreement with these critics is with their assertion that so-called protest writers do not ascribe to this pre-condition of literary art: the portrayal of the condition of man in his complexity. At a later stage this article will try to show that those writers mentioned by Ndebele as writers who do not fall within the "school of writers as storyteller", can actually be seen to be precisely what he say they are not.

It is the contention of this article that Ndebele's attacks on Tlali, Matshaba, Sepamla, among others, are too extreme and unjustified and only serve to reveal a biased criticism on his part. I shall also endeavour to show that some of Ndebele's works during the Aprtheid era also contain direct and overt political statements much in the same manner as the works of those he creiticizes. It would seem that this renders his attacks on them unjustified.

Ndebele certainly does not practice what he preaches. His fictional works during the Apartheid era are a violation of his own advocated literary rules. It is clear that in the midst of his literary intellectualization, Ndebele misses certain crucial points. Were he aware of these, one wonders if he would have ventured into his type of critical discourse. One the crucial points is that the search for true identity does not really stop in the discovery of 'inferiority' as he thinks; it begins with the realization of, and portrayal of, harsh reality. Only when harsh reality is bared and seen for what it is, is the illusion broken. And this is precisely what protest fiction writers do.

\section{Ndebele's Criticism and Counter-Criticism}

Writers of protest fiction write from an artistic viewpoint which Ndebele seeks to debase because of his objections to the content of their works. He would obviously assert that his whole argument is based on the universality of literary art which its broad acceptance is because of true human reflections and not due to particularly stressed geographical, social or political situations. It would also seem that he propagates the notion that the most vital art produced in a literary work is when the writer deals with wholesome human emotions in people's relationships. This, he claims, Kemal does to perfection. Ndebele argues that, unlike Kemal, protest fiction writers are excessively preoccupied with urban culture and its concerns. This implied avoidance of rural life in fiction constitutes to Ndebele an unawareness of the richness which such portrayals may yield to literary art. Ndebele concludes his argument on this point by saying that: 
writers, a commitment to political engagement (1984:43).

This is by inference an attempt to drive black South African city writers to the closed morality of conventional artistic literary beliefs. For the sake of upholding the artistic quality of literature, a writer must portray his reflections in a certain way and thereby maintain the conventional form of literary writing.

If Ndebele insists on his tireless propagation of a type of literary tradition in South Africa, he must clearly see that literature is so wide and varied that to try and confine it to a particular tradition for whatever reason, would be like trying to direct the wind in a particular direction.

It is also interesting that Ndebele makes no mention whatsoever of black South African writers who write in the vernacular. I think he omits mentioning them precisely because their writings are largely reflections of rural life. If he mentioned them he would have had to acknowledge that rural life is portrayed in black South African literature and that there are many streams of literary art. Or are we to surmise that so-called conventional literature can only be produced in English?

The fact that city writers write in English and that others, both in the city and rural areas, write in their vernacular, can only be ascribed to the readership. The reading public available to the city writer who writes in English is a literate readership. The city is also a home for different ethnic groups, black and white, and the English language plays a major role in communications between the different ethnic groups who live together in the city. It would be pointless for a writer who wants to address city dwellers and non-city dwellers to write in Zulu or Sotho, for instance. It is all a question of who the intended reader of a particular literature is.

Ndebele also overlooks the fact that literary art is best appreciated when the writer does not pre-plan his subjects and the manner of portrayal. Like any other art, a literary product must be the end-result of something which began with an inspiration. And what can better inspire an artist than his most pressing emotions or feelings? As the artist is rooted partly in his concrete material existence, he will definitely be influenced by his surroundings. These serve as an unlimited source of real-life inspiration. Otherwise, we will be forced to create a literary art which is trapped within the confines of literary art conventions and therefore deny ourselves the right to be different and do things differently in terms of literary expression.

Taking note of his critics, Sipho Sepamla says in an interview about protest fiction: 'They must take cognizance of the historical perspective that is governing the present-day writer'. He goes on to say: 'It is important to be aware that the present-day Black South African writer always expresses immediate experiences. Your Dostoyevsky, you Kafka are people we are exposed to. And again it should be borne in mind that writing relates to tradition' (1981:43).

This obviously means that protest-fiction writers base their writings on a tradition - their own tradition created by the circumstances in which they found themselves. Sepamla's argument can be advanced if one adds the fact that no literary tradition is complete in itself. Every tradition includes some elements of other traditions. To stress a particular form of literary art at the expense of another, as Ndebele does, is to do an injustice to the general trend of literature.

In response to the complaints of Sepamla, Tlali and Mutloatse about the criticism they have received from certain critics, Ndebele appears to contradict himself when he attempts to assert his critical position. He acknowledges that Tlali, in her novel Amandla, was 'not just reporting, she was telling a story' (1984:47). However, he goes on to criticize her for agreeing with what Sepamla said in the same interview when he asserted the importance of the reader. What Sepamla actually said was: 'we must go the people, for it is the man in the street we must listen to' (Ibid.).

Ndebele goes on to state that by this assertion the three writers seem to have established a premise that literary fiction which has direct or overt political content is what "the man in the street" really wants to read and how right he is! Surely Ndebele would agree that the literate black man, who can be regarded as the reader of literary works, is largely found in the cities.

This is not to say that one cannot find literate black readers of literature in the rural areas, but the black man who can identify with the experiences portrayed in protest fiction is almost invariably urban. After posing the theoretical question that if Sipho Sepamla were to listen to the man in the street, he would hear something different from what he claims, Ndebele claims another sort of mandate from the man in the street. This mandate derives from his assertion that black people have a tradition of storytelling which is not necessarily informed by the struggle against apartheid.

Ndebele conveniently neglects to tell his audience about the other side of this issue. In his effort to prop up his argument, he leaves out a crucial dimension of the debate. What he conveniently forgets to add is that the storytellers and their audiences were part of the masses and were subjected to the same inhuman treatment as any black person in South Africa. He apparently also forgets to point out that the little time they had for entertainment was spent on moments that create an illusionary world which by the very essence of the joy it gives, mirrors their cruel and sad existence. It was a form of escapism which allowed for a fleeting expression of happiness. The moment they left the sanctuary of their 
illusions (the buses and the trains); they were once again confronted with the existing reality in a country governed by those who were hell-bent to make their lives intolerable.

In his claims and examples, Ndebele tries to use pieces of different jigsaw puzzles to complete a new jig-saw puzzle. The fact of the matter is that the man in the street prefers the type of literary works written by those whom Ndebele criticizes. The man in the street wants to read about something with which he can really identify, something he can recognize, something that mirrors his own perceptions and his deep feelings. It is this reinforcement of his feelings and emotions that builds his resilience, if anything. Besides, in those stories that Ndebele claims appeal to the taste of 'the man in the street', the black man, contrary to Ndebele's claim, simply recounts some of his daily experiences - what he observes in the apartheid field of experience. He points out the absurdities of these experiences in the given situation in which he unfortunately finds himself.

In a paper delivered at the University of Bophuthatswana, entitled 'Actors and Interpreters: Popular Culture and Progressive Formalism', Ndebele also claims that the literary tradition of protest writers in South Africa has largely been influenced by its independence on white liberal influence. He asserts that most of the literature produced by black South Africans is directed at the white liberal reader. This type of literature, he argues, serves the purpose of constantly reminding the white man about his attitude in the hope that he will realize this injustice and change for the better. When asked a question on this issue, Miriam Tlali refuted this assumption. She points out:

In my writings I never try to copy somebody or adopt principles set down by scholars... I have always remarked that I'd like to present my stories with the black audience in my mind and I have never really intended to write for a white audience (1984:43)

This pronouncement should serve to remind critics to do their homework first before going public with their criticism. Of course, Ndebele would argue that Tlali's pronouncement is simply a defense against criticism of her work. But who really, for that matter, is Ndebele's intended reading public? If he can claim to write for a black audience, so can Tlali. There is a great deal in common in terms of projection in their respective works, as will be shown in this article.

The many tales produced by black South African writers, Ndebele's included, show the startling conditions and effects of life in the then authoritarian, racially segregated South Africa. It was a world these writers knew intimately. It was a world, the reality of which ironically perhaps, white South Africans had been schooled to reject. Assuming that this is so, where then lies Ndebele's claim that protest fiction is directed towards a people schooled to reject it?

I do not wish to profess ignorance of certain valid points Ndebele also makes. Many of them are, in any event, common knowledge. It is true that black South African writers depended largely on white liberals to have their works published. After all, many these liberals owned the means of publication. But it becomes an untruth when one claims that protest fiction literature was intended for consumption by white liberals. In a paper entitled 'Njabulo Ndebele and the Challege of the New', on the issue of black South African fiction and its intended readership, Mackenzie writes:

Ndebele evokes the sense of the writer's accountability to the majority African population, even if, as he acknowledges, the writing itself lands up in most cases in the hands of a white liberal readership (1990:6).

This is so only if by 'accountability' Mackenzie means that this type of literature serves to advances the black man's case in South Africa and as such becomes the political mouth-piece of the apparently silent majority. No wonder most of it was deemed undesirable and banned.

The silent majority were definitely the intended public of the 'protest fiction writers'. This literature was banned precisely because of that. It serves to propel the black man to stages of awareness about himself and life in South Africa. And if this public willingly appreciates what it is fed, the critic should ask himself why this is so. The black readers consume this type of literature for entertainment and to whip up emotions in themselves which will probably make them overcome their sense of fear, powerlessness, distrust and lost spontaneity.

Therefore, the answers to the question what constitutes acceptable literary art in South Africa, are varied and they should all be accepted as such. In a broad-minded evaluation of literary art in South Africa, Nadine Gordimer succinctly puts it thus:

I think that if you accept that for the writer, writing is his terrain...,because that is what he can do best, the question of protest writing-what it is, why anybody does it? - simply falls away and does not exist. Because to paraphrase "the poet is in the poetry", I think the protest is in the people. And if you write honestly about the life around you, the protest comes out of that. It is not a goal on its own (Source unknown).

This is the position that 'protest writers' have subconsciously assumed and have been forced to defend against attacks on their art by the likes of Ndebele. 
For the moment, I wish to confine myself to showing the inappropriateness of Ndebele's criticism by analyzing and showing the similarities between his fictional works and some fictional works of those he criticizes. In so doing, I hope to prove that his fictional works, if anything, fall within the same parameters of classification as the works of Mutloatse, Tlali and Sepamla.

Ndebele's major fictional work to date is undoubtedly the much acclaimed Fools and Other Stories for which he was awarded the Noma literary award. Fools and Other Stories contains five stories which deal with different experiences of black people.

The first story, entitled 'The Test', portrays a young black boy's world and how he relates to this world and those around him. In this story, minor but significant issues become major points of contention. The protagonist has to prove himself in a challenge against one of his friends. He has to prove himself by endurance. It is a test of strength against his rival to see who can best withstand the ferocity of the weather - in this case, rain and cold. An important dimension of this story is that of social commentary. Ndebele excels in depicting the lives of small boys in a dusty township through a particular event. Perhaps, by centering the story on small boys and exploring how they deal with their fears and troubles in a black township, Ndebele wishes to show the power of the seemingly helpless and innocent.

In the story, and in line with the tone of his criticism, Ndebele demonstrates the strength behind endurance and the satisfaction that can be derived from rising to the challenge to face hardship. Ndebele describes the boy after he had met the challenge thus:

He felt dry, but cold as he slipped into the blankets. He felt warm deep inside him, and as he turned over in bed looking for the most comfortable position, he felt all the pain. But, strangely enough, he wished he could turn around as many times as possible. There was suddenly something deeply satisfying and pleasurable about the pain. And as he slid into a deep sleep, he smiled feeling so much alive (1983:29).

The protagonist obviously feels gratified at having overcome the odds stacked against him. It is likely that is a literary assertion of Ndebele's critical perception that black South African writers should write as 'storytellers' - as he must himself presumably be doing in this story. He contends that, on the contrary they are glaringly political in their writings.

Later, in this article, it will be show how Ndebele contradicts himself in this regard and other points of disagreement shall be raised. For the moment the article is simply concerned with analyzing his stories.

'The Prophetess', the next story in the sequence, is written in much the same vein as 'The Test'. Ndebele achieves the same objective with this story as he does with 'The Test' - he celebrates the power of simplicity. The story is set in a township and revolves around a boy, who is sent by his sick mother to a prophetess to fetch 'holy water', which she hopes will heal her. On his way home with the water the boy gets knocked down by a man riding a bicycle and the bottle with the 'blessed' water breaks. When the boy gets home he fills another bottle with water and takes it to his mother. She thinks the water is blessed and after she has drunk it she immediately says she feels better. In this story Ndebele accurately portrays not only a township setting, but he celebrates the power of the mind - that belief has a healing power of its own.

The third story 'Uncle' is related by a small boy. In telling the story through the consciousness of a small boy, Ndebele excels in the portrayal of the simplicity of innocence in the midst of suffering. It is the story about the relationship of the boy (the narrator) and his uncle whom he holds in high esteem.

The boy's uncle is a musician and he visits the boy and his mother after a long time. He teaches the boy all the values central to their lives: the roles of the family, the ancestor's ethics, morality, sex and racial pride.

The story is rather long and seems to have been deliberately inflated with apparently unnecessary descriptions of the township which make it approach the length of a novella in scope.

'The Music of the Violin' is a story in which a black man's values and attitudes are subjected to scrutiny. It is a story about withdrawing from reality in favour of a world of artificiality and falsehood. In the process there occurs the distortion of people's existential modes as they substitute reality with artificiality. The story concerns a small boy, Vukani, his father, a school inspector and his mother, a nursing sister. They clearly belong to the aspiring middle-class and are proud of their status in society. Vukani does not like playing the violin because to him it is source of constant humiliation and embarrassment.

He is torn between his desire to free himself from doing what he does not like, that is, playing the violin, and what he regards to be his duty to his parents; to obey and please them. A critical point in the story occurs when his parents want him to play the violin for their visitors, Dr Zwane and his wife, Beatrice. In a final act of defiance, the boy refuses to play the violin and his mother is shocked. Vukani's sister adds insult to injury by accusing her mother of pomposity, 
artificiality and selfishness.

All the stories in this collection except the title story, 'Fools', are told either in the first - or third - person and the protagonist is a school boy who is on the brink of adolescence. In all the stories the boy is weak, timid, nervous and frequently humiliated, either by other boys or his mother. He is set apart socially from other boys in the township by virtue of his parents' education; the mother is a nurse in all the stories and the father is involved in school education.

Through the boy protagonists in these stories, Ndebele portrays a celebration of victory by defiance, endurance and fulfillment - the boy refuses to play the violin, he takes an unauthorized, run in the rain, he is disobedient and he sheds all belief in the supernatural. Each story ends on a note of triumph and fulfillment.

'Fools' is perhaps Ndebele's best short story. It is a story about a middle-aged teacher, Zamani, who disgraces himself in the eyes of the community by raping a schoolgirl and embezzling church funds. The teacher's interactions with the girl's brother, Zani, gradually propel him to self-realisation.Zani comes to the township of Charterston fired up with radical political ideas and a mission to make the people aware of the oppressive system to which they are subjected. He wishes to prompt them to do something. Zamani, on the other hand, yearns for perpetual darkness. He lives life as it comes and tries to extract whatever he can from it for the sole purpose of satisfying his desires.

Whilst Zani is thwarted in his immature act of protest, Zamani is rescued from his miserable and humiliating existence by the encounter with the aggressive white man at the picnic ground which provides him with the ultimate test of his existence as a black man. In a dramatic about-turn, he triumphs over brutality and emerges a mature man with increased awareness of himself and the terrible conditions of his existence.

Another of Ndebele's short stories to which attention should be drawn is 'Death of a Son'. It is about the cruelty of injustice. A man, Bantu, is stripped of his dignity as a person by his failure to stand and face the system. Bantu's son is killed by the police and he is humiliated before he can get his son's body back from them. It seems here that despite Ndebele's attempts to distance himself from much contemporary black South African literature, his stories in Fools and 'Death of a son' ascribe to Sipho Sepamla's idea of literature. In a personal interview in which Sipho Sepamla was asked what his central concern was in his writing, he responded: 'I write about the condition of man'.

From the foregoing synopsis of Ndebele's stories, it can be seen that Ndebele also writes about the condition of man, more particularly, of the black man in South Africa. The theme of apartheid and the necessity of struggle are not avoided in his stories. For a man who preaches the universality of artistic literary expression, he seems to have done very little to represent his ideas in his art. His stories include a strong component of overt politics.

In his writings he gives personalized accounts of the black man's condition in South Africa - his humiliation, his fears, racial pride, his weaknesses and his strengths, and above all, the necessity to overcome. All this is portrayed as a direct consequence of the brutality of the apartheid system. It is quite obvious that Ndebele, like the writers he criticizes, bases his stories on specific events.

He does acknowledge though, as do those he criticizes, that a writer cannot write in a vacuum. In the 'Turkish Tales...' article, in which he exalts the literary abilities of the Turkish writer Yasher Kemal, he states:

\begin{abstract}
What so readily seems to undercut the autonomy of art is its subject matter: the specificity of setting, the familiarity of character, recognizable events in either recent or distant history, and other similar factors that ground a work firmly in the time and space (1984:44).
\end{abstract}

The target of this criticism are works like those of Sepamla and Tlali. It should be pointed out here that the two short stories, 'Fools' and 'Death of a Son' in particular, are stark evidence of Ndebele's apparent confusion in the treatment of theory and practice especially when compared and contrasted with the works of those he criticizes. He clearly does not practice what he preaches when he writes about the literary position he opposes. To him the pre-occupation of the black South African writer with the African experience has been largely superficial. This superficiality, he writes,

Comes from the tendency to produce fiction that is built around the interaction of surface symbols of the South African reality. These symbols can easily be characterized as ones of either good or evil, even more accurately, symbols of evil on the one hand, and symbols of the victims of evil on the other hand (1984:44).

And because of the black writer's pre-occupation with this type of literary projection, he precludes one of Ndebele's most cherished ideas about literary art - that of the writer as a storyteller. The component of storytelling must of necessity, according to Ndebele, always prevail in artistic fiction.

\title{
4. In Closing
}

Before Ndebele even ventures to criticize the black writer for his unconventional style of literary art, writers like Mutloatse 
had already stated their intentions with regard to the method which they will apply in their works. This was a conscious defiance of existing literary conventions with which they were obviously quite familiar. In his introduction to the anthology Forced Landing, Mutloatse (1987) defiantly makes the point that black protest fiction writers will deliberately ignore the so-called 'literary convention' in pursuit to telling their stories their way, critics or no critics.

One wonders, with this self-conscious assertion of the composition of their work, where then, lies the justification for Ndebele's criticism?

\section{References.}

Achebe C, 1975. Morning Yet on Creation Day. London: Heinemann.

Cromell, G. "Evaluating Protest Fiction" English in Africa, Vol. 7, No. 1, March 1980.

Gordimer, N. (Source unknown)

Hernadi, P. 1978. What is Literature? London: Indiana University Press.

Mackenzie, C. Njabulo Ndebele and the Challenge of the New. (Unpublished paper)

Mutloutse, M (ed) 1987. Forced Landing. Braamfontein: Ravan Press.

Nazareth, P. 1972. Literature and Society in Modern Africa. Nairobi: East African Literature Bureau.

Ndebele, N. 1983. Fools and other Stories: Braamfontein: Ravan Press.

Ndebele, N. 1991. Rediscovery of the Ordinary: Essays on South African Literature and Culture. Johannesburg: COSAW.

Ndebele, N. "Turkish Tales and Some Thoughts on South African Fiction", Staffrider, Vol. 1, 1984.

Ndebele, N. 2003. TheCry of Winnie Mandela. Claremont: David Philip.

Ngugi, T. 1981. Writers in Politics. London: Heinemann.

Nkosi, L. 1965. Home of Exile. London: Heinemann.

Okri, B. (Exact source unknown)

Sepamla, S. Personal Interview with the Writer, Johannesburg, 6 May 1992.

Shava, P,V. 1989. A People's voice: Black South African Writing in the Twentieth Century. London: Zed Books.

Tlali, M. Interview with the Writer, 20 October 1993.

Vaughan, M. "The Writer as a Storyteller" African Studies Seminar paper. March 1988.

Weeklek, R. 1992. A History of Modern Criticism, Volume 8. New Haven: Yale University Press. 